\title{
A review of nanotechnology with an emphasis on Nanoplex
}

\author{
Rupali Nanasaheb Kadam*, Raosaheb Sopanrao Shendge, Vishal Vijay Pande
}

Sanjivani College of Pharmaceutical Education and Research, Kopargaon, Ahmednagar, Maharashtra, India

\begin{abstract}
The use of nanotechnology based on the development and fabrication of nanostructures is one approach that has been employed to overcome the challenges involved with conventional drug delivery systems. Formulating Nanoplex is the new trend in nanotechnology. A nanoplex is a complex formed by a drug nanoparticle with an oppositely charged polyelectrolyte. Both cationic and anionic drugs form complexes with oppositely charged polyelectrolytes. Compared with other nanostructures, the yield of Nanoplex is greater and the complexation efficiency is better. Nanoplex are also easier to prepare. Nanoplex formulation is characterized through the production yield, complexation efficiency, drug loading, particle size and zeta potential using scanning electron microscopy, differential scanning calorimetry, X-ray diffraction and dialysis studies. Nanoplex have wide-ranging applications in different fields such as cancer therapy, gene drug delivery, drug delivery to the brain and protein and peptide drug delivery.
\end{abstract}

Uniterms: Nanotechnology. Nanoplex/formulation. Nanoplex/characterization. Nanoplex/applications

\begin{abstract}
O uso da nanotecnologia baseada no desenvolvimento e na fabricação de nanoestruturas é uma abordagem que tem sido empregada para superar os desafios envolvidos nos sistemas de liberação de fármacos convencionais. A formulação de nanoplexos é a nova tendência na nanotecnologia. Um nanoplexo é um complexo formado pela nanopartícula do fármaco com poplieletrólito de carga oposta. Tanto fármacos catiônicos quanto aniônicos formam complexos com polieletrólitos opostamente carregados. Comparado com outras nanoestruturas, o rendimento dos nanoplexos é maior e a eficiência de complexação é melhor. Nanoplexos são, também. De mais fácil preparação. A formulação de nanoplexo é caracterizada pelo rendimento de produção, eficiência de complexação, carga do fármaco, tamanho de partícula e potencial zeta, utilizando microscopia eletrônica de varredura, calorimetria exploratória diferencial, difração de raios $\mathrm{X}$ e estudos de diálise. Os nanoplexos têm aplicações amplas em diferentes campos, como terapia antineoplásica, liberação em terapia gênica, liberação cerebral de fármaco, liberação de fármacos protéicos e peptídicos.
\end{abstract}

Unitermos: Nanotecnologia. Nanoplexos/formulação. Nanoplexos/caracterização. Nanoplexos/ aplicações.

\section{INTRODUCTION}

Nanotechnology is the science that deals with the nanolength scale and with processes that occur at the molecular level. There are a number of examples from nature of structures with nanodimensions such as red blood corpuscles (RBCs), viruses, DNA and water molecules (Ochekpe, 2009a). Even our history has

\footnotetext{
*Correspondence: R. N. Kadam. Sanjivani College of Pharmaceutical Education and Research. Kopargaon, Ahmednagar, Maharashtra, India. E-mail: rupalikadam700@gmail.com
}

a number of examples that prove we have exploited the advantages of technology in one or another form. The term 'nanotechnology' has also been used in other fields of science such as electronics, physics and engineering for many decades. Nanotechnology has led to tremendous progress in these fields. Nanotechnology is a multidisciplinary field, representing a convergence of the basic sciences and applied disciplines such as biophysics, molecular biology, and bioengineering (Manivannan, 2011). It has had a powerful impact in various fields of medicine, including cardiology, immunology, ophthalmology, oncology, endocrinology and pneumology, 
and in highly specialized areas such as gene delivery, brain targeting and oral vaccine formulation. Nanotechnology provides intelligent materials, systems and devices for better pharmaceutical applications (Bhattacharrya et al., 2009; Malakar et al., 2012; Lamba, 2006).

Nanoparticles are defined as particulate dispersions or solid particles with size in of the range 10-100 nm. Drugs are dissolved, entrapped, encapsulated or attached to nanoparticle matrices (Mohanraj,Chen, 2006; Manmode, Sakarkar, Mahajan, 2009)

\section{TYPES OF NANOSTRUCTURES}

\section{Nanosuspensions}

A nanosuspension is defined as a very finely colloid, biphasic, dispersed, solid drug particle in an aqueous vehicle, of size below $1 \mu \mathrm{m}$, without any matrix material, stabilized by a surfactant and a polymer, prepared using a suitable method for drug delivery applications through various routes of administration such as the oral, topical, parenteral, ocular and pulmonary routes (Nagare et al., 2012; Prabhakar, Balakrishna, 2011; Verma, Bindal, 2012).

\section{Solid lipid nanoparticles}

Solid lipid nanoparticles are novel potential colloidal carrier systems used as alternative materials to polymers. They are identical to oil-in-water emulsions used for parenteral nutrition, but the liquid lipid of these emulsions is replaced by a solid lipid. They have good compatibility and low toxicity and are physically stable. Lipophilic drugs are better delivered using solid lipid nanoparticles (Ekambaram, Sathali, Priyanka, 2012; Pragati et al., 2009).

\section{Nanofibres}

Nanofibres are defined as fibres with diameter less than 50-500 $\mathrm{nm}$. They have an extremely high surface area-to-weight ratio compared with conventional nonwovens. Nanofibres have good filtration properties (Kattamuri et al., 2012; Dineshkumar et al., 2012).

\section{Nanocomposites}

Nanocomposites have superior strength and fracture toughness. Nanocomposites have good mechanical, optical, electrical and thermal properties (Sambarkar, Patwekar, Dudhgaonkar, 2012).

\section{Carbon nanotubes}

Carbon nanotubes (CNTs) are allotropes of carbon. The length-to-diameter ratio of these nanostructures is greater than 1,000,000. CNTs exhibit good carrier properties and are used to transport biomolecules to target sites. These biomolecules include a diverse array of compounds such as drugs, vaccines, small peptides, proteins, nucleic acids, vitamins and sugars (Hirlekar et al., 2009; Mishra, 2013; Gurjar et al., 2013).

\section{Nanopores}

Materials with pore-sizes in the nanometre range are of special interest for a broad range of industrial application because of their outstanding properties with regard to thermal insulation and controllable material separation and release and their suitability as templates or fillers for chemistry and catalysis. Aerogels are examples of nonporous materials. They are produced using sol-gel chemistry (Wannunu, 2012).

\section{Liposomes}

Liposomes are small artificial vesicles (50-100 nm) developed from phospholipids. They have been used as drug carriers as a result of their ability to prevent degradation of drugs, reduce side effects and target drugs to sites of action. Liposomes are used for transdermal drug delivery (they enhance the skin permeation of drugs of high molecular weight and poor water solubility) and as carriers for delivery of drugs (they reduce toxicity) in the treatment of ocular diseases (Ochekpe, 2009b).

\section{Polymeric nanoparticles}

Polymeric nanoparticles are solid colloidal particles with diameter ranging from $1 \mathrm{~nm}$ to $1000 \mathrm{~nm}$. Polymeric nanoparticulate systems developed using biodegradable and biocompatible polymers offer interesting options for controlled drug delivery and drug targeting (Jawahar, Meyyanathan, 2012).

\section{Polymeric micelles}

Polymeric micelles are self-assembled core-shell nanostructures formed in aqueous solutions consisting of amphiphilic block polymers. Micelles are formed in aqueous solutions when the concentration of the block copolymer increases above a certain concentration or critical micelle concentration (Xu, Ling, Zhang, 2013). 


\section{Dendrimers}

Dendrimers are branched macromolecules. They have a central core unit with a high degree of molecular uniformity, a narrow molecular weight distribution, specific size and shape characteristics and a highlyfunctionalized, terminal surface. The cellular uptake in dendrimers is through endocytosis, and drugs are bound to dendrimers within cells (Mishra, 2011; Shishu, Maheshwari, 2009; Trivedi et al., 2012).

\section{Nanocapsules}

Nanocapsules are vesicular or reservoir systems in which oil/water is essentially confined to a cavity surrounded by a tiny polymeric membrane. Nanocapsules can be targeted to specific cells and locations within the body after they are injected intravenously or subcutaneously (Dineshkumar et al., 2013).

\section{Nanoplex}

A nanoplex is a drug nanoparticle complex with an oppositely charged polyelectrolyte. Cationic or anionic drugs are made to reach with oppositely charged polyelectrolytes to form Nanoplex (Chew, 2012a, 2012c).

\section{Magnetic nanoparticles}

Magnetic nanoparticles form a class of engineered particulate materials of particle size less than $100 \mathrm{~nm}$ that can be manipulated using external magnetic fields. Magnetic nanoparticles consist of a core of a polymer such as dextran coated with an inorganic substance such as iron oxide (Indira, Lakshmi, 2010).

\section{Nanoemulsions}

Nanoemulsions/submicron emulsions are thermodynamically stable, transparent (translucent) dispersions of oil and water stabilized interfacial films of surfactant and cosurfactant molecules. Their droplet size is less than $100 \mathrm{~nm}$ (Indira, Lakshmi, 2010).

\section{Quantum dots}

Quantum dots are semiconducting materials consisting of a semiconductor core provided with a shell to improve optical properties. Their properties originate from their physical size, with the radius being in the range 10-100 $\AA$. These have had a significant impact on imaging, in-vitro and in-vivo detection and analysis of biomolecules, immunoassay and DNA hybridization. They are used in non-viral vectors for gene therapy. Their main application is in labeling cells and as therapeutic tools for cancer treatment (Patel, 2012).

\section{Carbon allotrope graphenes}

Graphene is a substance made of pure carbon, with atoms arranged in a regular hexagonal pattern similar to that of graphite but in a one-atom-thick sheet. It is an allotrope of carbon whose structure is a single planar sheet of sp2-bonded carbon atoms that are densely packed in a honeycomb crystal lattice. Hence, graphenes may be considered as the mother of graphite, fullerene and CNTs (Bera et al., 2010).

\section{NANOPLEX: A NEW TREND IN NANOTECH- NOLOGY}

A nanoplex is a drug nanoparticle complex with an oppositely charged polyelectrolyte. A cationic or anionic drug is made to react with an oppositely charged polyelectrolyte to form a nanoplex.

Most promising candidates for drugs exhibit lowsaturation solubility in the aqueous phase. Making these drugs more soluble is the aim of research presently because these drugs exhibit low oral bioavailability. As a result, frequent dosing is required, imposing a pill burden and financial burden on patients. There are three major ways of enhancing bioavailability: (1) transformation of API into its highly soluble salt form, (2) producing crystalline nanoparticles (or nanoAPI) of API and (3) delivering the API in its amorphous form (Ando, Radebaugh, 2005)

Forming a salt of a weak organic acidic or basic drug is the easiest way of increasing the saturation solubility of the drug. But salt formation does not guarantee the enhancement of the saturation solubility (Rabinow, 2004). NanoAPI formulations are not limited to acidic or basic drugs because the particles are reduced to nanosize and the behaviour of these particles is according to the OstwaldFreundlich solubility theory.

The Ostwald-Freundlich equation states that saturation solubility enhancement by nanoionization is significant only for sizes much greater than $100 \mathrm{~nm}$ (Grant, Brittain, 1995). NanoAPI with sizes of $\sim 150-200 \mathrm{~nm}$ hves been found to exhibit an only $15 \%$ increase in saturation solubility over their microscale counterparts. The established nanoAPI formulation techniques (e.g. highpressure homogenization, wet milling) are not promising 
for producing nanoAPI with size less than $100 \mathrm{~nm}$. Therefore, advances in nanoAPI preparation techniques are needed to enhance bioavailability.

A different strategy to increase the apparent solubility is to generate a metastable state of the amorphous form of the API. Dissolution of the amorphous API results in a highly supersaturated solution, with an apparent solubility that is significantly greater than the saturation solubility of the crystalline counterparts. The high supersaturation level consequently enhances drug absorption across the gastrointestinal lumen, resulting in enhanced bioavailability, provided that the supersaturation can be maintained for a period sufficient for absorption. The significant thing about amorphous forms is that the generation of high supersaturation levels has been shown to translate to enhanced bioavailability in vivo (Yang, Johnton, Williams, 2010; Tam et al., 2008).

Amorphous API is typically prepared in the form of a microscale solid dispersion of the drug that is stabilized using high-transition-temperature polymers (e.g., hydroxypropylmethylcellulose (HPMC), poly(ethylene glycol)) by cogrinding, hot melt extrusion or antisolvent precipitation techniques (Yamada et al., 1999; Verreck et al., 2003). The stabilizer (generally up to $50 \%(\mathrm{w} / \mathrm{w})$ ) plays two important roles: (1) preventing recrystallization of the amorphous API during storage by occupying its high-energy surfaces and (2) inhibiting precipitation of the dissolved drug, which prolongs the supersaturation. However, it reduces the drug loading.

Amorphous API formulations, yet, suffer from the drawbacks of (1) low drug loading and (2) a strong tendency to recrystallize after dissolution. The latter drawback results in slow dissolution rates of the amorphous API, mostly when slowly dissolving stabilizers (e.g., HPMC) are used, leading to low apparent solubility. The in-solution recrystallization tendency can be overcome by developing a nanoscale formulation, in which the specific surface area leads to a high dissolution rate. A number of nanoscale amorphous API (or amorphous nanoAPIs) have been successfully prepared using a wide range of techniques (e.g., antisolvent precipitation, sonoprecipitation) with a drug loading of up to $90 \%$ (w/w) (Chen et al., 2006; Matteucci et al., 2006; Dhumal et al., 2008)). These techniques, however, have some weaknesses, including intricate processes, a heavy use of organic solvents, high expenses related to energy and a wide size distribution in the product.

\section{Preparation of amorphous drug Nanoplex}

Depending on the solubility (which is a function of $\mathrm{pH}$ ), a drugs is dissolved in an acidic or basic aqueous

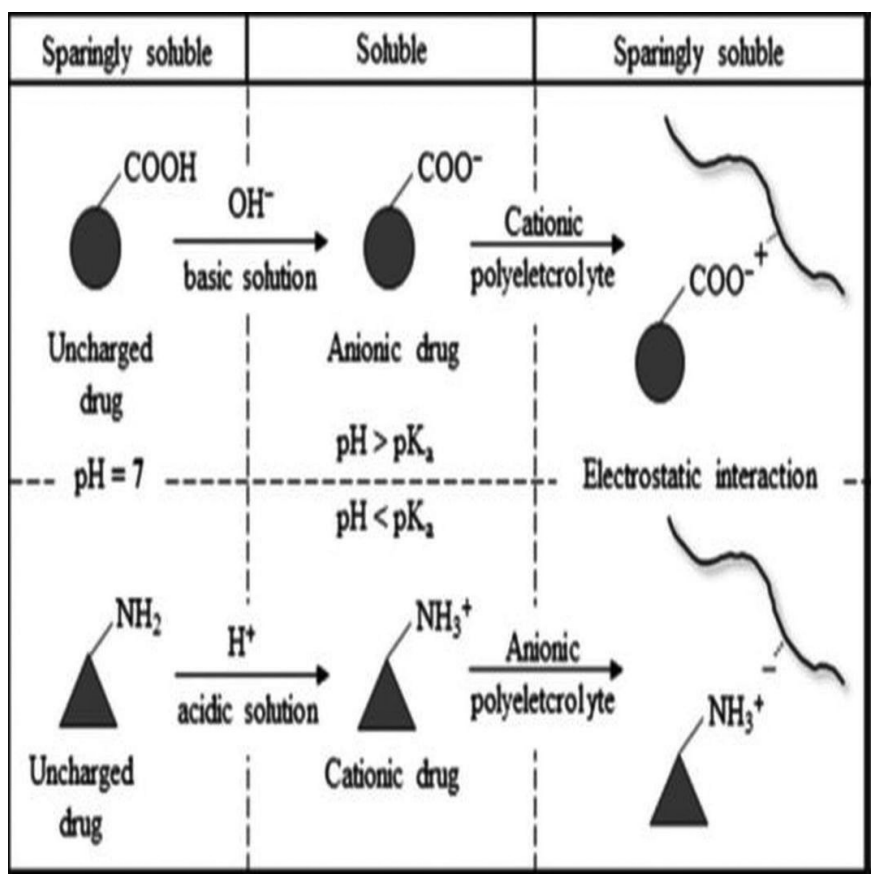

FIGURE 1 - Preparation of nanoplex.

solution to form it cation or anion, respectively. Amphoteric drugs forms cations when they are dissolved in aqueous acetic acid solutions $(\mathrm{AA})(\mathrm{pH}<\mathrm{pKa})$, whereas acidic drugs forms anions when they are dissolved in aqueous $\mathrm{KOH}$ solutions $(\mathrm{pH}>\mathrm{pKa})$. The ionized drug solution is subsequently added to the oppositely charged aqueous polyelectrolyte solution, upon which a drug-polyelectrolyte electrostatic interaction takes place to form a soluble drug-polyelectrolyte complex, as illustrated in figure 1. At a certain concentration, the value of which depends on the drug hydrophobicity, drug-PE complexes aggregate as a result of the interdrug hydrophobic interaction and finally form an insoluble drug nanoplex in the presence of a salt. The role of the salt is to provide a charge-screening effect to minimize repulsions of the like-charged PE chains, which can inhibit complex aggregation, as shown in figure 2 . The strong drug-PE electrostatic interaction prevents the drug molecules from assembling into ordered crystalline structures upon precipitation, resulting in the amorphous nanoplex (Cheow, 2012c).

\section{Advantages of Nanoplex}

1. The method of preparation of Nanoplex is simple as only mixing of two solutions, of the drug and PE, is involved.

2. Nanoplex preparation does not require a heavy use of solvents. 


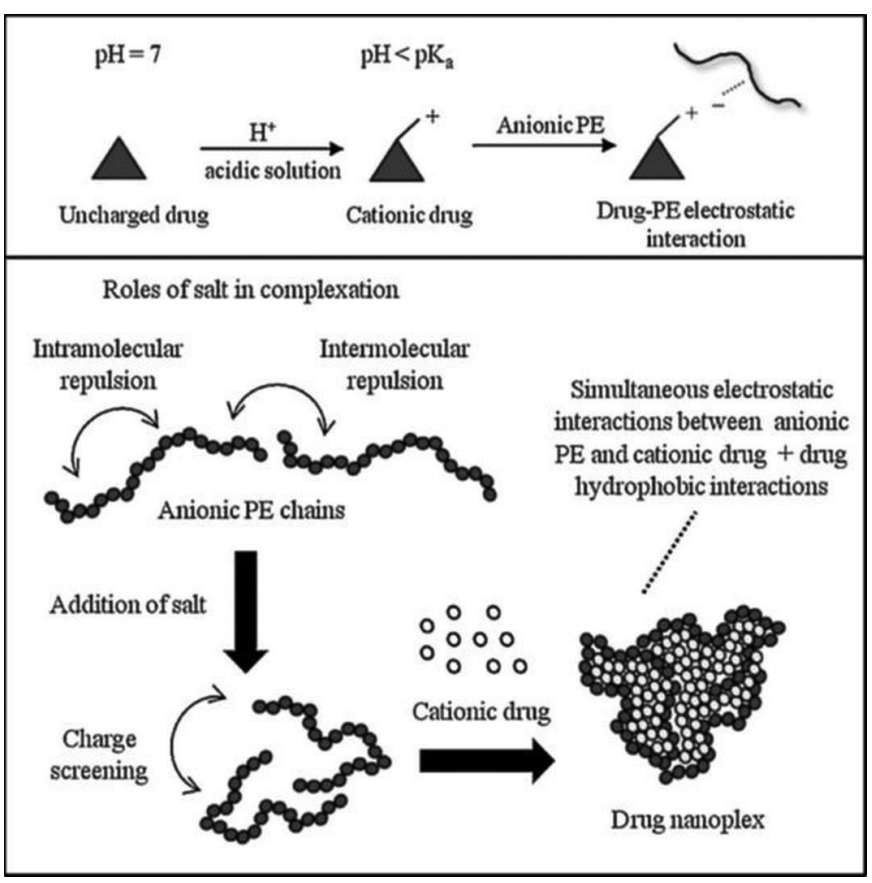

FIGURE 2 - Role of salt in nanoplex formulation.

3. The energy requirement for nanoplex preparation is minimal compared with other nano formulations.

4. Nanoplex formation is a fast process.

5. There is no need to use sophisticated instruments to prepare Nanoplex.

\section{Mechanism of nanoplex formation}

The water-insoluble drug is first dissolved in an acidic or basic medium to form an anionic or cationic drug solute. Afterwards the ionized drug solution is mixed with an oppositely charged polyelectrolyte solution, which initiates the drug-polyelectrolyte electrostatic interaction and simultaneously charge neutralization as shown in figure 3. The drug solute is transformed back to its sparingly soluble form upon charge neutralization, leading to a loss of solubility, and hence there is rapid precipitation and formation of the nanoscale drug-polyelectrolyte complex. The combination of rapid precipitation and strong electrostatic interactions between the drug and the polyelectrolyte prevents the drug molecules from assembling into ordered crystalline structures. As a result, an amorphous drug-polyelectrolyte nanoparticle complex is formed (Cheow, 2012b).

\section{Role of salt in nanoplex preparation}

The salt plays an important role in the self-assembly of the nanoplex through its electrostatic charge shielding

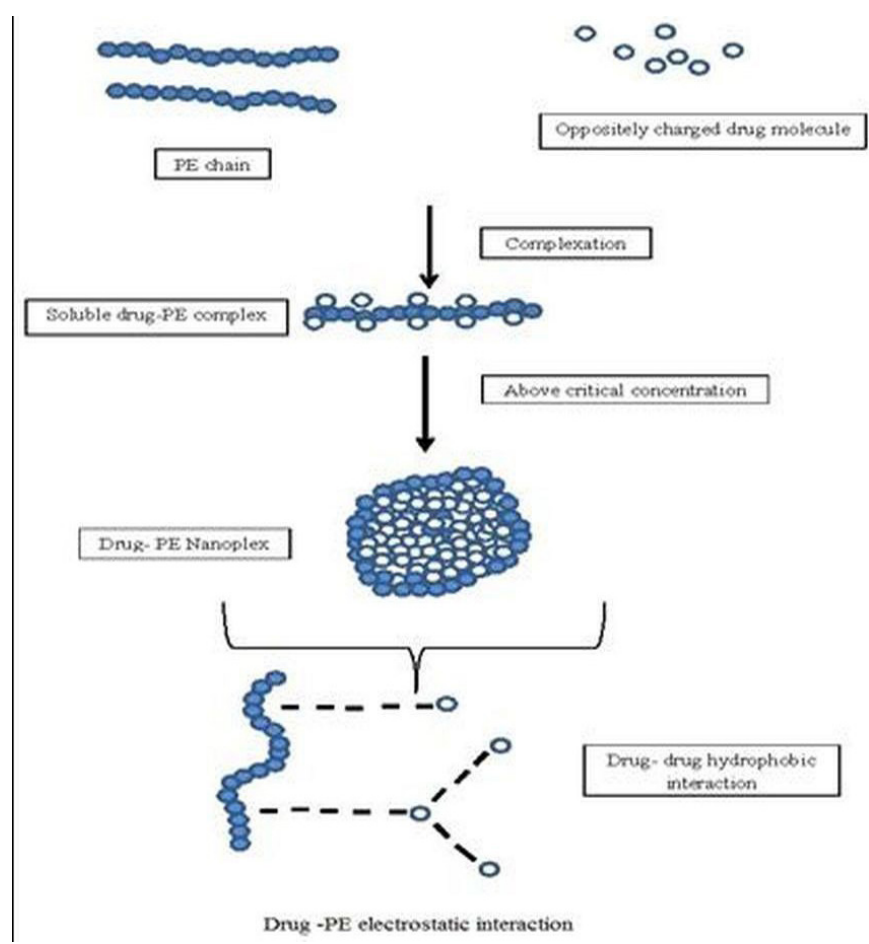

FIGURE 3- Mechanism of nanoplex formulation.

function. In the absence of salt, intermolecular repulsions between the like-charged PE chains inhibit their spatial interactions. The same can be said for the drug, with the charged drug molecules repelling if there is no salt, thus hindering a compact assembly of drug molecules. The higher solubility of the drug in a solution of lower ionic strength further contributes to the lack of inter-drug hydrophobic interactions (Singh, Caram-Lelham, 1998). Consequently, there is no nanoplex precipitation in the absence of a salt despite the oppositely charged interactions. Instead, soluble drug-PE complexes may be present, reminiscent of the soluble amphiphilic drug and PEs previously investigated. In the presence of a salt, the shielding of charge enables the $\mathrm{PE}$ chains to be in closer contact with each other. Likewise, the drug molecules are also in closer contact, which leads to the formation of a core-shell nanoplex, which then precipitates upon drug. Nevertheless, the charge-shielding effect of the salt must not be too strong, or it will (i) inhibit the electrostatic interactions between the drug molecules and $\mathrm{PE}$ involved in complex formation or (ii) neutralize the charge interactions between the drug and PE in the alreadyformed complex, resulting in de-complexation (Hugerth, Sandlot, 2001).

\section{Evaluation of Nanoplex}

- Complexation efficiency. This is defined as the mass of a drug that forms a complex with the poly- 
electrolyte relative to the initially added drug. It is calculated by measuring the optical density of the supernatant after the first centrifugation of the nanoplex suspension (Cheow, 2012c).

- Production yield. It is the ratio of the weight of the drug and polyelectrolyte initially added to the weight of the dry nanoplex formed after freeze drying (Cheow, 2012c).

- Drug loading. This is the actual amount of drug present in the nanoplex powder. It is calculated by dissolving $5 \mathrm{mg}$ of the nanoplex powder in $20 \mathrm{ml}$ of ethanol and measuring the absorbance of the solution after centrifugation and filtration (Cheow, 2012c).

- $\quad$ Particle size analysis. The particle size of the nanoplex is analysed using a particle size analyser (Chew, 2012c).

- Zeta potential. The zeta potential of the nanoplex is determined using a zetasizer (Cheow, 2012a).

- Differential scanning calorimetry (DSC). DSC is performed to determine the interactions between the drug and polyelectrolyte. The interactions are also determined on the basis of their melting points, and the difference is calculated using a DSC instrument. The results are presented in the form of graphs (Cheow, 2012c).

- Powder X-ray diffraction. Powder X-ray diffraction patterns of samples are determining using a powder $\mathrm{X}$-ray diffractometer. This gives an idea about the nature of the sample (Cheow, 2012a).

- $\quad$ Scanning electron microscopy. The surface morphology of the sample is observed using a scanning electron microscope (Cheow, 2012c).

- Dissolution study. Dissolution testing of the nanoplex is carried out using the dialysis bag method to determine the drug release (Cheow, 2012c).

- $\quad$ Saturation solubility study. The solubility of the drug and that of the formulation are determined using the orbital flask shaker method. The concentration of the drug is determined from the absorbance, through spectrophotometric analysis (Cheow, 2012c).

- $\quad$ Stability study. The stability of the nanoplex is tested by placing it in an environmental stability chamber, and its drug content is determined (Cheow, 2012c).

\section{Applications of Nanoplex}

\section{Enhancement of solubility and dissolution rate}

Preparing Nanoplex of poorly water-soluble drugs (i.e., class II and class IV drugs) enhances their solubility and dissolution rate and ultimately bioavailability. Solubility enhancement reduces the dose requirement of a drug (Cheow, 2012c).

\section{Drug delivery to the brain}

The blood brain barrier (BBB) is the most important factor limiting the development of a new drug for the central nervous system. The BBB is characterized by relatively impermeable endothelial cells with tight junctions, enzymatic activity and active efflux transport systems. It effectively prevents the passage of watersoluble molecules from the blood circulation into the CNS and can reduce the concentration of lipid-soluble molecules in the brain through the action of enzymes or efflux pumps. Consequently, the BBB only permits selective transport of those molecules that are essential for brain function. It has been suggested that nanoparticles may be used as non-viral gene delivery vectors and that they have great potential in therapeutic applications for several diseases such as HIV-1, AIDS, dementia and cerebral ischaemia. Nanoplex have been evaluated for the specificity and efficiency of quantum dot (QD) complexes [with MMP-9-siRNA (nanoplex) in down-regulating the expression of the MMP-9 gene in the brain micro vascular endothelial cells (BMVECs) that constitute the BBB. Adela Bonoiu et al. demonstrated the use of a novel nanoplex siRNA delivery system in modulating MMP-9 activity in BMVECs and other MMP-9-producing cells. This application will prevent neuroinflammation and maintain the integrity of the BBB (Bonoiu, et al., 2009 ).

\section{Nanoplex for gene delivery}

Non-viral vector-mediated gene therapy is currently one of the most attractive strategies used due to their biocompatibility, biodegradability, minimal cytotoxicity, lack of pathogenicity and low immunogenicity. The development of non-viral vectors consisting of dendrimers, liposomes and cationic polymers is the focus of research currently. Cationic polymers have been found to be useful in neutralizing the anionic nature of DNA, thus efficiently condensing DNA and allowing it to enter cells easily. Cationic polymers represent an interesting class of vectors in plasmid DNA delivery formulations. Various cationic polymers including synthetic amino acid polymers such as poly(1-lysine) and polyethyleneimine (PEI), natural DNAbinding proteins such as histones, carbohydrate-based polymers such as chitosan and various dextran derivatives have been reported (Thomas, 2010b).

\section{Drug targeting in cancer treatment}

Many different cationic lipids have been synthesized 
for non-viral vectors. The general structure of a cationic lipid has three parts: (1) a hydrophobic lipid anchor group, which helps form the micellar structure and can interact with cell membranes; (2) a linker group, such as an ester, an amido group or a carbamate; and (3) a positively charged head-group, mainly composed of cationic amines. Cationic cholesterol derivatives could be selected as the anchor group because of their high transfection activity and low toxicity. The linker group of cationic cholesterol derivatives controls the conformational flexibility, degree of stability, biodegradability and gene transfection efficiency. Cationic nanoparticles composed of $\mathrm{OH}-\mathrm{Chol}$ (NP-OH) could deliver siRNA with a high transfection efficiency in vitro when the nanoparticle/siRNA complex (nanoplex) is formed in an $\mathrm{NaCl}$ solution (Hattori et al., 2008).

\section{Drug delivery of proteins and peptides}

Significant advances in biotechnology and biochemistry have led to the discovery of a large number of bioactive molecules and vaccines based on peptides and proteins. The development of suitable carriers remains a challenge because the epithelial barrier of the gastrointestinal tract limits the bioavailability of these molecules and they are susceptible to gastrointestinal degradation by digestive enzymes. Proteins are charged molecule that forms a complex with polyelectrolyte therefore, they are suitable candidate for nanoplex formulation (Woitiski, Ribeiro, Neufeld, 2007; Ranjan et al., 2010).

\section{CONCLUSION}

Most orally administered drugs are amphiphilic in nature and soluble in a weak acid or base. They can be transformed into amorphous Nanoplex by the simple complexation method. The preparation of a nanoplex requires only the mixing of two solutions at ambient conditions. It is also solvent-free and fast. It requires little energy and produces uniform-sized nanoparticles with a high complexation efficiency, drug loading and production yield.

\section{REFERENCES}

ANDO, H.Y.; RADEBAUGH, G.W. Property-based drug design and preformulation. In: TROY, D. B. (Ed.). Remington: the science and practice of pharmacy. 21. ed. Philadelphia: Lippincott Williams \& Wilkins, 2005. p.720-744.
BERA, D.; QIAN, L.; TSENG, T.; HOLLOWAY, p.H. Quantum dots and their multimodal applications: a review. Materials, v.3, n.4, p.2260-2345, 2010.

BHATTACHARYYA, D.; SINGH, S.; SATNALIKA, n.; KHANDELWAL, A.; JEON, S. Nanotechnology, big things from a tiny world: a review. Int J. u-. e-Ser Sci. Technol., v.2, n.3, p.29-38, 2009.

BONOIU, A.; MAHAJAN, S.D.; LING, Y.; DING, H.; KENTYE YONG, NAIR, B.; REYNOLDS, J.L.; SYKES, D.E.; IMPERIALE, M.A.; BERGEY, E.J.; SCHWARTZ, S. A.; PRASAD, p.N. MMP-9 gene silencing by a quantum dotsiRNA nanoplex delivery to maintain the integrity of the blood brain barrier. Brain Res., v.1282, p.142-155, 2009.

CHEN, J.F.; ZHANG, J.Y.; SHEN, Z.G.; ZHONG, J.; YUN, J. Preparation and characterization of amorphous cefuroxime axetil drug nanoparticles with novel technology: highgravity antisolvent precipitation. Ind. Eng. Chem. Res., v.45, n.25, p.8723-8727, 2006.

CHEOW, W. S.; HADINOTO, K. Green amorphous nanoplex as a new supersaturating drug delivery system. Langmuir, v.28, n.15, p.6265-6275, 2012a.

CHEOW, W.S.; HADINOTO, K. Green preparation of antibiotic nanoparticle complex as potential anti-biofilm therapeutics via self-assembly amphiphile-polyelectrolyte complexation with dextran sulfate. Colloids Surf. B. Biointerfaces., v.92, p.55-63, 2012b.

CHEOW, W.S.; HADINOTO, K. Self-assembled amorphous drug-polyelectrolyte nanoparticle complex with enhanced dissolution rate and saturation solubility. J. Colloid Interface Sci., v.367, n.1, p.518-526, 2012 c.

DHUMAL, R.S.; BIRADAR, S.V. ; YAMAMURA, S.; PARADKAR, A.R.; YORK, p.Preparation of amorphous cefuroxime axetil nanoparticles by sonoprecipitation for enhancement of bioavailability. Eur. J. Pharm. Biopharm., v.70, n.1, p.109-115, 2008.

DINESHKUMAR, B.; KRISHNAKUMAR, K.; BHATT, A.R.; JOHN, A.; PAUL, D.; CHERIAN, J.; UMAA, K.; SURESH, S. Nanofibers: potential applications in wound care management. Adv. Poly. Sci. Tech., v.2, n.3, p.30-32, 2012. 
DINESHKUMAR, B.; KRISHNAKUMAR, K.; JOHN, A.; PAUL, D.; CHERIAN, J.; PANAYAPPAN L. Nanocapsules: a novel nano-drug delivery system. Int. J. Res. Drug Deliv., v.3, n.1, p.1-3, 2013.

EKAMBARAM, p.; SATHALI, A.; PRIYANKA, K. Solid Lipid Nanoparticle: A Review. Sci. Revs. Chem. Commun., v.2, n.1, p.80-102, 2012.

GRANT, D.J.W.; BRITTAIN, H.G. Solubility of Pharmaceutical Solids. In: BRITTAIN, H. G (Ed.) Physical characterization of pharmaceutical solids;., New York; CRC Press, 1995. p.321-386. (Drugs and the Pharmaceutical Sciences, v.70).

GURJAR, p.N. ; CHOUKSEY, S.; PATIL, G.; NAIK, N.; AGRAWAL, S. Carbon Nanotubes: Pharmaceutical Applications. Asian J. Biomed. Pharm. Sci., v.3, n.23, p.8$13,2013$.

HATTORI, Y.; HAGIWARA, A.; DING, W.; MAITANI, Y. $\mathrm{NaCl}$ improves siRNA delivery mediated by nanoparticles of hydroxyethylated cationic cholesterol with amido-linker. Bioorg. Med. Chem. Lett.., v.18, n.19, p.5228-5232, 2008.

HIRLEKAR, R.; YAMAGAR, M.; GARSE, H.; MOHIT, v.I.J.; KADAM, v.Carbon Nanotubes and its Application: A Review. Asian J. Pharm. Clin. Res., v.2, n.4, p.17-27, 2009.

HUGERTH, A.; SANDLOT, L.O. The effect of polyelectrolyte counterion specificity, charge density, and conformation on polyelectrolyte-amphiphile interaction: The carrageenan/ furcellaran-amitriptyline system. Biopolymers, v.58, n.2, p.186-194, 2001.

INDIRA, T.K.; LAKSHMI, p.K. Magnetic Nanoparticle - A Review. Int. J. Pharm. Sci. Nanotechnol., v.3, n.3, p.1035$1042,2010$.

JAWAHAR, n.; MEYYANATHAN, S.N. Polymeric nanoparticles for drug delivery and targeting: a comprehensive review. Int. J. Health Allied Sci., v.1, n.4, p.217-223, 2012.

KATTAMURI, S.B.; POTTI, L.; VINUKONDA, A.; BANDI, v.; CHANGANTIPATI, S.; MOGILI, R.K. Nanofibers in $\mathrm{p}$ harmaceuticals- a review. Am. J. Pharmtech Res., v.2, n.6, p.187-212, 2012.

LAMBA, D. A brief review on nanotechnology. Impulse, v.2, p.58-63, 2006.
SHISHU, G.; MAHESHWARI, M. Dendrimers: the novel pharmaceutical drug carriers. Int. J. Pharm. Sci. Nanotech., v.2, n.2, p.493-502, 2009.

MALAKAR, J.; GHOSH, A.; BASU, A.; NAYAK. A. Nanotechnology: A Promising Carrier for Intracellular Drug Delivery System. Int. Res. J. Pharm., v.3, n.2, p.3640, 2012.

MANIVANNAN, R. Nanotechnology: a review. J. App. Pharm. Sci., v.1, n.2, p.8-16, 2011.

MANMODE, A.S.; SAKARKAR, D.M.; MAHAJAN, n.M. Nanoparticles-tremendous therapeutic potential: a review. Int. J. Pharm. Tech. Res., v.1, n.4, p.1020-1029, 2009.

MATTEUCCI, M.E.; HOTZE, M.A.; JOHNSTON, K.P. ; WILLIAMS, R.O. Drug nanoparticles by antisolvent precipitation: mixing energy versus surfactant stabilization. Langmuir, v.22, n.21, p.8951-8959, 2006.

MISHRA, I.N. Dendrimer: A Novel drug delivery system. $J$. Drug Deliv. Ther., v.1, n.2, p.70-74, 2011.

MISHRA, R.; MISHRA, A. Review on potential applications of carbon nanotubes and nanofibers. Int. J. Pharm. Rev. Res., v.3, n.1, p.12-17, 2013.

MOHANRAJ, v.J.; CHEN, Y. Nanoparticles - a review. Trop. J. Pharm. Res., v.5, n.1, p.561-573, 2006.

NAGARE, S.K.; GHUGHURE, S.M.; SALUNKE, S.B.; JADHAV, S.G.; DHORE, R.J. A review on: Nanosuspensionan innovative acceptable approach in novel delivery system. Uni. J. Pharm., v.1, n.1, p.19-31, 2012.

OCHEKPE, n.A.; OLORUNFEMI, p.O.; NGWULUKA N. C. Nanotechnology and drug delivery. Part 1: Nanostructures for drug delivery. Trop. J. Pharm. Res., v.8, n.3, p.265-274, 2009a.

OCHEKPE, n.A.; OLORUNFEMI, p.O.; NGWULUKA, n.C. Nanotechnology and drug delivery. Part 2: Nanostructures for drug delivery. Trop. J. Pharm. Res., v.8, n.3, p.275-287, 2009b.

PATEL, R.P. ; JOSHI, J.R. An overview on nanoemulsion: A novel approach. Int. J. Pharm. Sci. Res., v.3, n.12, p.46404650, 2012. 
PRABHAKAR, C.H.; BALAKRISHNA, K. A review on nanosuspension in drug delivery. Inter. J. Pharma Bio Sci., v.2, n.1, p.549-558, 2011.

PRAGATI, S.; KULDEEP, S.; ASHOK, S.; SATHEESH, M. Solid lipid nanoparticle: a promising drug delivery technology. Inter. J. Pharm. Sci. Nanotech. v. 2, n.2., p.509$516,2009$.

RABINOW, B.E. Nanosuspensions in drug delivery. Nat. Rev. Drug Discov. ., v.3, n.9, p.785-796, 2004.

RANJAN, A.; POTHAYEE, n.; SELEEM, M.; JAIN, n.; SRIRANGANATHAN, n.; RIFFLE, J.S.; KASIMANICKAM, R. Drug delivery using novel Nanoplex against a Salmonella mouse infection model. $J$. Nanopart. Res., v.12, p.905-914, 2010.

SAMBARKAR, p.P. ; PATWEKAR, S.L.; DUDHGAONKAR, B.M. Polymer nanocomposites: an overview. Int. J. Pharm. Pharma. Sci., v.4, n.2, p.60-65, 2012.

SINGH, S.K.; CARAM-LELHAM, n.Thermodynamics of kappa-carrageenan-amphiphilic drug interaction as influenced by specific counterions and temperature: A microcalorimetric and viscometric study. J. Colloid Interface Sci., v.203, n.2, p.430-446, 1998.

TAM, J.M.; MCCONVILLE. J.T.; WILLIAMS, R.O.; JOHNSTON, K.P. Amorphous cyclosporine nanodispersions for enhanced pulmonary deposition and dissolution. $J$. Pharm. Sci., v.97, n.11, p.4915-4933, 2008.

THOMAS, J.J.; REKHA, M.R.; SHARMA, C.P. Dextranglycidyltrimethylammonium chloride conjugate/DNA nanoplex: a potential non-viral and haemocompatible gene delivery system. Int. J. Pharm., v.389, n.1-2, p.195-206, 2010a.

THOMAS, J.J.; REKHA, M.R.; SHARMA, C.P. Dextranprotamine polycation: an efficient nonviral and haemocompatible gene delivery system. Colloid Surface B. Biointerfaces, v.81, n.1, p.195-205, 2010 b.
TRIVEDI, v.; BHIMANI, B.; PATEL, U.; DASLANIYA, D.; PATEL, G.; VYAS, B: Dendrimer: Polymer of $21^{1 \text { st }}$ Century. Int. J. Pharm. Res. Biosci., v.1, n.2, p.1-21, 2012.

VERMA, A.; BINDAL, M.C. Nanosuspension: advantages and disadvantages. Ind. J. Nov. Drug Deliv., v.4, n.3, p.179$188,2012$.

VERRECK, G.; SIX, K.; VAN DEN MOOTER, G.; BAERT, L.; PEETERS, J.; BREWSTER, M.E. Characterization of solid dispersions of itraconazole and hydroxypropylmethylcellulose prepared by melt extrusion - part I. Int. J. Pharm., v.251, n.1-2, p.165-174, 2003.

WANUNU, M. Nanopores: A journey towards DNA sequencing. Phys. Life Rev., v.9, n.2, p.125-158, 2012.

W O I T IS K I, C.; R I B EIR O, A.; NEUFELD, R. Bioencapsulation into nanoplex carrier for oral insulin delivery. In: INTERNATIONAL WORKSHOP ON BIOENCAPSULATION, 15., 2007, Vienna, Au., Annals. p.720-744. p.4-13.

XU, W.; LING, p.; ZHANG, T. Polymeric micelles, a promising drug delivery system to enhance bioavailability of poorly water-soluble drugs. J. Drug Deliv., p.1-15, 2013.

YAMADA, T.; SAITO, n.; IMAI, T.; OTAGIRI, M. Effect of grinding with hydroxypropyl cellulose on the dissolution and particle size of a poorly water-soluble drug. Chem. Pharm. Bull., v.47, n.9, p.1311-1313, 1999.

YANG, W.; JOHNSTON, K.P. ; WILLIAMS, R. O. Comparison of bioavailability of amorphous versus crystalline itraconazole nanoparticles via pulmonary administration in rats. Eur. J. Pharm. Biopharm., v.75, n.1, p.33-41, 2010.

Received for publication on $18^{\text {th }}$ April 2014 Accepted for publication on $07^{\text {th }}$ January 2015 
